after its retirement in 2010 and take astronauts back to the Moon, puts the telescope within reach. "If Orion is available, and we have a really simple, but significant problem on the JWST, wouldn't it make sense to ensure that astronauts could go to the JWST if they could fix it?" asks Weiler.

But the harsh radiation environment in deep space would probably make it far too dangerous for astronauts, says John Mather, the JWST's chief project scientist at Goddard. And a robot mission could probably do very little. It might be able to give the satellite a good shake to loosen a stuck solar panel, says Mather, but would be unlikely to cope with more complex tasks. And in its repair efforts, it might dirty the telescope's outer mirrors.

Mather says the JWST's team is now conducting a feasibility study to find out whether a docking port could be added. But given that it is unlikely that a problem so simple it could be fixed by a robot will surface during the mission, Mather says he is not keen to add something to the already grossly over-budget telescope. "If it costs more than a few thousand dollars," he says, "I'm not interested."

Repair missions to spacecraft closer to Earth than the JWST have so far been rare, but not unheard of. An orbiting mission to study the Sun was rescued by a service mission carried out by astronauts on the space shuttle Challenger in 1984. The first servicing mission to Hubble in 1993 fixed a critical error, installing a corrective optics system to fix the telescope's blurry vision. It has since been serviced a further three times.

Geoff Brumfiel

\title{
Disgraced official was paid work bonus
}

Further troubling reports have surfaced in the case of a disgraced US official accused of political interference in the workings of the Endangered Species Act. It has been disclosed that Julie MacDonald, former deputy assistant secretary for fish, wildlife and parks at the Department of the Interior (DOI), received a performance award of nearly $\$ 10,000$ in 2005 . Yet the report of an investigation into her conduct, released on 27 March this year, reveals that MacDonald violated federal regulations while in that position. She resigned on 1 May.

The report, by the DOI's office of inspector general, paints a portrait of a woman determined to minimize the Endangered Species Act's effect on the economy. It includes evidence from colleagues that she heavily edited science reports from the field despite having no formal scientific training, and bullied and intimidated field scientists into producing documents along the lines she wanted.

Observers say the case highlights how appointees of President George W. Bush can and have pushed political agendas within federal agencies. "She was a little bit more overt and transparent and shameless about her political antics and dealings, but she was not a lone ranger," says Jamie Rappaport Clark, executive vice-president of the environmental group Defenders of Wildlife in Washington DC and former director of the US Fish and Wildlife Service.

MacDonald was also chastised for sharing "nonpublic information with private sector sources", including a nonprofit lobby group called the California Farm Bureau Federation; the Pacific Legal Foundation, a law firm that represents development interests; and a friend from an online game. The report outlines how she sent internal departmental documents to a friend in the game World of Warcraft "to have another set of eyes give an unfiltered opinion of them". MacDonald could not be reached for comment by Nature.

The latest chapter comes from Steve Davies, editor of the newsletter Endangered Species \& Wetlands Report. Davies learned through a Freedom of Information Act request that MacDonald received a Special Thanks for Achieving Results award of $\$ 9,628$ in March 2005, during the period covered by the investigation. The DOI will not detail the reasons for the award; it says the justification is included in her performance evaluation, which is private.

Meanwhile, Democrats in Congress are investigating MacDonald for her role in removing the Sacramento splittail fish from the endangered species list. MacDonald owns a farm in a floodplain that is a habitat for the fish, according to an investigation by the Contra Costa Times, a newspaper in California. Emma Marris

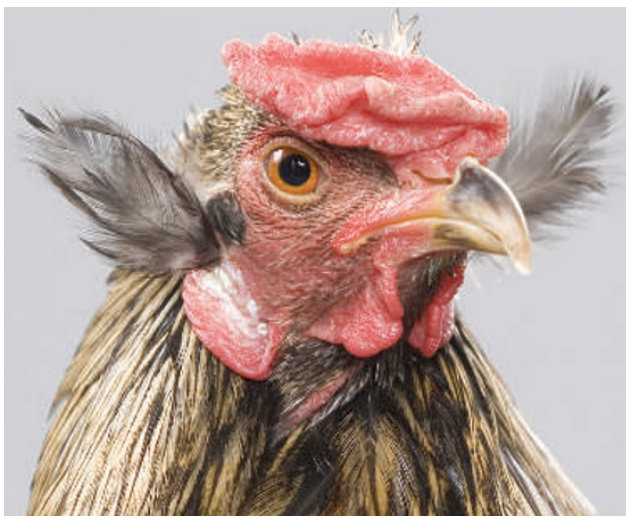

It's all relative: Chile's Araucana chicken shares its DNA with ancient birds from Polynesia.

contribution to the field, but warns that the small fragments obtained from ancient DNA may tell only part of the story. The final verdict will require more extensive DNA data to make a full family tree of both modern and ancient breeds, he says.

Archaeologist Terry Jones at California Polytechnic State University in San Luis Obispo, who has studied prehistoric Polynesian contact in the New World, is less circumspect. "It's essentially unequivocal evidence," he says.

Evidence of contact between the communities has been put forward in the past. In 1947, Thor Heyerdahl famously filmed his journey by raft from Peru across the Pacific to try to prove that South Americans could have settled the Pacific islands; although the theory was at odds with much of the evidence.

More recently, Jones, along with Kathryn Klar at the University of California, Berkeley, has argued that the Polynesians introduced complex fish hooks and sewn plank canoes to the Chumash and Gabrielino Indians in southern California and the Mapuche Indians in Chile (K. A. Klar and T. L. Jones Am. Antiquity 70,
457-484; 2005). Others argue that Polynesians must have visited the tropical coast of South America in order to bring back the sweet potato and the bottle gourd. The voyage to South America is no more daunting than other trips Polynesians are known to have made.

Even so, one of the co-authors on the chicken study, Atholl Anderson at the Australian National University, Canberra, is wary of overestimating the extent of this cultural diffusion without further study. Although the chickens provide hard evidence of transoceanic contact, the evidence that large-scale cultural exchange occurred remains largely circumstantial, he says.

Brendan Borrell 